\title{
DEFINITION AND DELIMITATION OF PERIPHERIES OF VISEGRAD COUNTRIES
}

\author{
Ladislav NOVOTNÝ1 • Marcin MAZUR² • Tamás EGEDY \\ ${ }^{1}$ Pavol Jozef Šafárik University in Košice, Faculty of Science \\ Department of Geography, Jesenná 5, 040 01, Košice, Slovakia \\ ladislav.novotny@upjs.sk \\ ${ }^{2}$ Institute of Geography and Spatial Organization, Polish Academy of Sciences \\ Twarda 51/55, 00-818 Warsaw, Poland \\ m.mazur@twarda.pan.pl
}

${ }^{3}$ Research Centre for Astronomy and Earth Sciences, Hungarian Academy of Sciences Geographical Institute, Budaörsi str. 45, H-1112, Budapest, Hungary

egedy@gmx.net

\begin{abstract}
The aim of this article is to analyze various methods and approaches to peripherality, and to introduce proposals for delimitation of peripheral areas in Visegrad countries. First, the content of approaches to the identification of peripherality is assessed, followed by emphasis on the role of spatial scale in the delimitation of peripheral areas. Then, the strict and broad understanding of peripherality is described considering the role of locality in its conceptualization. The quantitative approach to the delimitation of peripheries in the Visegrad countries presented in the following part of the article is in line with the precise understanding, as it is assumed to be more sufficient for the research of economic development in peripheral areas. In the final part of the article, examples of delimitation of peripheries in whole V4 area are introduced based on distance-based measures, equidistant-based measures, and on the approach employing the potential index. This allowed for revealing and validating some regularities in the spatial distribution of peripheral areas but also revealed the role of subjective assumptions entering the delimitations.
\end{abstract}

Key-words: peripherality, marginality, locality, Visegrad countries, peripheral areas.

\section{Introduction}

Irrespective of its spatial scale, the term rurality is very often accompanied by the terms peripherality and marginality. This highlights close ties between the concepts of urban-rural continuum or dichotomy and the concept of core-periphery represented in line with Reynauld (1981) or Castree at al. (2013) the binary geographical relation between a centre and its margins. However, rural does not regularly mean peripheral or marginal, and at the same time peripheral areas may include rural as well as urban areas. Ambiguity in the use of the terms peripherality and marginality, together with various approaches to the definition of rurality often results in misunderstandings and vague conclusions. Peri- 
pherality does not determine whether a given locality or area is categorized as rural but it has significant impact on its social and economic development potential. Therefore the aim of this article is to sort out the various approaches to peripherality and marginality out, to introduce methods for the identification of peripheral areas in Visegrad countries and by their application to clarify the distinction between rural and peripheral.

Peripherality and marginality in geography can definitely be considered as terms referring to spatial polarization. However, while some authors (e.g. Jussila 1998; Leimgruber 1994) consider them as synonyms, others (e.g. Andreoli 1994; Pelc 2007; Máliková and Spišiak 2013; Šebová 2013) emphasize their different meanings. As noticed by Seidl and Chromý (2010) and Šebová (2013), marginality, peripherality and even rurality are perceived more or less synonymic in Czech geography, represented for example by Havlíček and Chromý (2001) and also in Polish geography.

Reynaud (1981) identified central and peripheral areas on the basis of economic flow in the area. As a consequence, some areas were neither core nor peripheral, because the economic flow there was so weak that those areas could be considered as isolated from the core-periphery system. Following this, Andreoli (1994) and Schmidt (1998) emphasize that peripheral areas, although at its edge, are integrated into the system, while marginal areas are isolated from it. This means that peripheries are also necessary for the functioning of the core, while the role of marginal areas in relation to the functioning of the core or generally to the global system is minimal. Such an approach to distinguishing between peripherality and marginality has recently found wider application in Slovak (e.g. Malíková and Spišiak 2013; Šebová 2013) and also in Czech geography (Seidl and Chromý 2010).

Andreoli (1994) as well as Hurbánek (2004) also highlight the differences between a broad and narrow focus on the peripherality and marginality. In line with both authors, marginality and peripherality are characterized by different attributes in the narrow understanding, but might be perceived as synonyms in the broad understanding. Broadly perceived marginality as well as broadly perceived peripherality include both, narrowly perceived peripherality and narrowly perceived marginality. However, even for narrow perception, it is desirable to highlight the proximity of both terms. As emphasized by Šebová (2013), due to changing social and economic relations in space, many peripheral areas are threatened by marginalization, while some marginal areas may become integrated into the systems and become peripheral.

In relation to the broad definition of peripheral or marginal regions, in Czech and Slovak geography (Čermák 2005; Malíková and Spišiak 2013) an alternative term underexposed area as opposed to exposed area is sometimes used. Exposure of a given area is then defined as an aggregate of its spatial location and also its role or importance in the social and economic system. In Polish geography such areas are often labelled as problem areas in contrast to areas of success.

\section{Content approaches to the identification of peripherality}

Peripherality is a very general phenomenon and despite many attempts to simplify its definition, it is not possible to cover all its dimensions by a single indicator. When reflecting on a wide range of scientific papers focused on peripherality (Leimgruber 1994; Schmidt 1998; Havlíček et al. 2005; Malíková and Spišiak 2013; Poláčková and Potomová 2010; 
Šebová 2013 and others), it is possible to distinguish two main groups of approaches to the research of this phenomenon: the objective and the subjective.

The approaches included in the objective group identify peripherality or marginality on the basis of mathematically clear processable statistical data. Based on the nature of source data, several approaches can be distinguished within this group. Šebová (2013) analysed the approach of different authors (e.g. Leimgruber 1994; Schmidt 1998; Havlíček et al. 2005) identified the following approaches within this objective group: geometric, ecologic, physical-geographical, economic, social-demographic, political, cultural, and religious. However, such segmented approaches are overlapping or some approaches can include more others. Therefore, in line with Šebová (2013) and considering the importance given to individual approaches by individual authors, within the objective group we suggest distinguishing the following subgroups:

- Geometric - this approach operates with distances whether expressed by time or metric units. Geometrically peripheral areas are usually located at the edge of larger spatial units, in case of administrative units at its border. Due to the integration of Central European countries into the Schengen area the role of state borders within this area diminished, but the role of natural barriers as natural borders still remains significant. Within the geometric approach increasing attention has been paid to the accessibility of cores (regardless of intra-Schengen area borders) defined usually as towns or cities with a given number of inhabitants or administrative function (see e.g. Halás 2008) or even accessibility to main traffic routes (Horñák 2006).

- Political - generally, in line with Schmidt (1998) it is possible to conclude that within any larger political or administrative unit, there are areas that, due to different reasons, are less interesting or important for those who hold political or decision making power. In the integrated European Union, this can occur in various spatial scales from local almost to Pan-European.

- Ecological - it is possible to distinguish two basic attitudes towards ecological peripherality, which are partially opposing. The decisive factor is whether the periphery is identified on the basis of state of environment or on its potential for the development of human activities. Geographers (Leimgruber 1994; Schmidt 1998 or Spišiak 2000) usually consider as peripheral protected natural areas or areas with conditions not suitable for human activities (high-mountain landscape, polar regions, etc.). Another view of ecological peripherality is represented predominantly by environmentalists who consider as peripheral those areas, where the environment is strongly influenced by human activities.

- Economic - this approach to peripherality was together with geometrical outlined within the first location theories by von $\mathrm{p}$ Weber or Christaller (cf. Blažek and Uhlír 2002). A real boom in the identification of peripherality on economic aspects (as well as others within the objective group) occurred in the second half of the 20th century, when the quantitative revolution allowed the development of statistical methods based on a wide range of economic indicators describing the spatial polarization of economic activities and processes

- Social - originates and is used mainly in sociology. It processes demographic and social indicators to identify marginalized people and their groups within society. This marginalization is usually related to the segregation of racial, ethnic, religious, 
sexual orientation, and other minorities. In geography, spatial aspect in the distri-

bution of these people is stressed (e.g. Gurung and Kollmair 2005).

All the mentioned approaches within the objective group are closely related and usually even influence each other. Therefore, peripheral areas identified by different approaches are often very similar. While geography became fixed mainly to objective approaches, improved during the quantitative revolution in the second half of the 20th century, subjective approaches to the research of peripherality and marginality prevailed in sociology. However, geographers assumed that quantitative methods were not fully sufficient for the identification and interpretation of all various dimensions of peripherality. It resulted in the implementation of approaches from the subjective group into geography. Subjective approaches to the research of periphery are based on subjective perception of the observer. In line with Schmidt (1998) or Havlíček et al. (2005), two basic subgroups of approaches are to be distinguished according to the position of the observer, who might be an inhabitant of the peripheral area (internal perception) or to be from outside the area (external perception).

Within both, internal and external perceptions, it is possible to identify positive (optimistic), negative (pessimistic) or indifferent (unconcerned) attitudes to peripherality (Šebová 2013). A positive attitude is seen as development potential of the area. People who trust in the positive future of the area tend to start a business, establish local action groups, or other activities improving the given area.

\section{Spatial dimensions of peripherality}

Whether objective or subjective approaches are used, spatial scale is one of the key factors in identification of peripheral areas. As emphasized by Havlíček (2003) or Hurbánek (2004), an area identified as central in large-scale might be included in the peripheral area in small scale and vice versa. Therefore, Halás (2008) proposes to sort the different spatial scales of the research of peripherality into three basic groups:

- The macro-level: Global and transnational scale

- Position of countries and international groups of countries within the world

- Position of countries or states within continents

- Position of "spatially larger" regions within continents

- The mezzo-level: Regional scale

- Position of regions within countries or states

- Position of micro-regions within "spatially larger" regions

- The micro-level: Local scale

- Position of communities within the regions or micro-regions

- Position of areas within intra-urban or intra-rural structures

To emphasize the different categorization of areas depending on the spatial scale considered, Halás (2014) includes "semiperiphery" - an area between core and periphery into the idea of spatial polarization. In this way he can easily visualize the changing position of areas when shifting from macro-level to micro-level (Fig. 1).

It is clear that within the areas considered as semiperipheral at a higher level, some core and peripheral areas were identified at a lower level, when mezzo- and micro-regional centres were taken into consideration in addition to macro-regional centres. In 

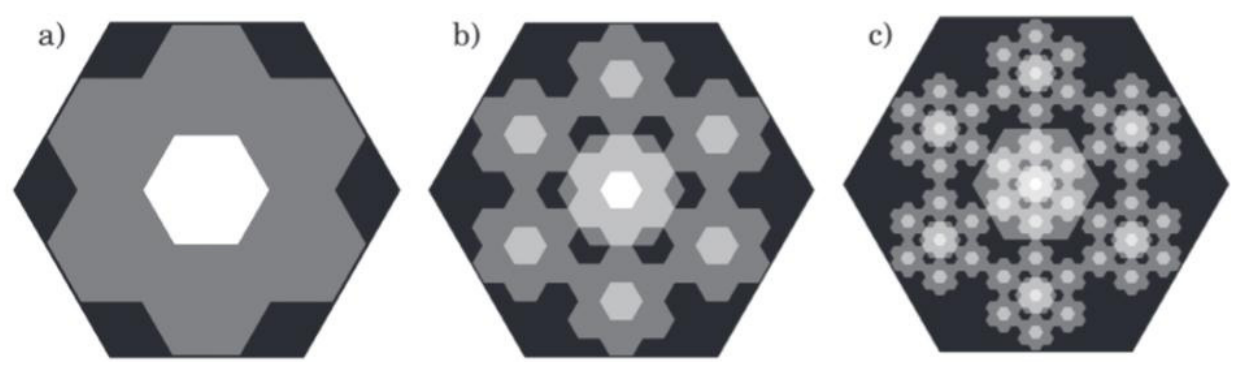

Fig. 1. Theoretical model of spatial distribution of core (white colour), semiperipheral (grey) and peripheral (dark grey) areas at macro-regional, mezzo-regional and micro-regional scale. Source: Halás (2014).

the same way semi-peripheral areas emerged within core areas. As there are undeniable relations between different spatial levels of peripherality, Leimgruber (1994) as well as many other authors consider it to be necessary to cover all dimensions of peripherality to apply their multi-scale approach.

\section{Location in the concept of peripherality}

Irrespective of spatial scale, whether considering objective or subjective approaches, it is clear, that the location of a given area plays a significant role in defining peripherality. From this point of view, it is also possible to distinguish a broad and a strict understanding of peripherality.

The broader identifies a periphery as an area with some positive process exclusion, an area of particular need for external development process support (Kohli 2004). In this sense a periphery includes a certain underdeveloped dimension, which is the result of the assumption itself. Therefore often the description of peripherality contains categories such as problem area (peripheral), area of success (non-peripheral) or other similar. Such a way of understanding periphery and peripherality that is close to a narrow understanding of marginality in Slovak and partially also Czech geography, can be named qualitative, because it describes features of peripheral areas, which are the result of a lack in some endogenous potential.

Strictly understood a periphery is a feature of an area or place, which is a direct consequence of its location only on the given spatial background. Peripheral location and underdevelopment in some dimension should be strictly distinguished as separate features, although usually firmly related to each other and commonly co-existing. Then, location itself, even when perceived as a condition for development of a given area (e.g. proximity to the development core, benefits of agglomeration), can be described formally (Borgatti and Everett 2000). Such a concept of peripherality can be named quantitative, because according to chosen indicators it is possible to compare the potential impact of location on development at a quantitative level. The given peripheral area can be seen as an area of success or a problem area in terms of the chosen dimension of development; and location is only one of the potential conditions of such a state. 


\section{Quantitative approach to the delimitation of peripheries in Visegrad countries}

As was already mentioned, periphery is a multidimensional term. However, for the purposes of further analyses, it is understood strictly, as a feature of inconvenient location itself which can be assessed by a certain quantitative index. A need for quantitative expression of peripherality is a natural consequence of its fluent change in space. Typical "central" features of a place are replaced by "peripheral" ones gradually, going along a continuous axis from some abstract ideal centre at one end to an abstract ideal periphery at the other. Delimitation of peripheral regions by sharp borders should be treated no more seriously than as some conventional approximation done in regard of certain practical purposes. In reality borders of peripheries are fuzzy and one can talk about a given area in the context of level of peripherality rather than in the context of absolute identification or exclusion of it. To conclude a periphery can be defined as an area, which is distant to a certain potential. However, even if one agrees with these basic statements concerning the term periphery and the role of peripheral location in the development of entrepreneurship, there are still some crucial assumptions needed to define peripheries precisely. In general, there are three aspects to consider: the spatial extent of analysis, distance metrics and potential expression.

First of all, the spatial extent of elaboration needs to be established. It determines the final results outstandingly and the role of these assumptions is very often underestimated. Analysis of the results of the peripheries' delimitation in the context of the neighbourhood of Visegrad countries is more than sufficient to illustrate the significance of this aspect and its influence on the final result (compare Fig. 2-4). Some peripheral areas of these countries can compose a central zone of Visegrad countries, when the analysis is conducted in the case of a broader extent of Visegrad countries put together. The same phenomenon exists on other scales as well. One can easily find certain peripheries of Visegrad countries, which are placed in vicinities of big external centres, like Berlin or Vienna for example. Therefore it is clearly seen that such areas should not be perceived as peripheral in a European context.

The distance between spatial units can be understood very broadly and expressed in many different ways. In general, distance is an inversion of spatial accessibility. The simplest expression of spatial accessibility has a dual nature. A given place can be accessible or not. Going from a qualitative to a quantitative scale of accessibility measurement, its domain should be defined first. One can assess accessibility not only in the context of physical distance, but also for example in the sense of connection frequency, its convenience, travel time, safety or economic costs (Komornicki et al. 2010). Even after acceptance of using physical distance as a sufficient way of accessibility measurement, e.g. due to lack of other data, there is still a more precise definition of distance measurement needed. To be more realistic, the measurement can take into consideration environmental barriers and road network layout, or even the quality of this network. On the other hand it can simply take into account the shortest line.

Also potential can be expressed in many different ways. Beyond access to population or its certain groups, especially accessibility to economic potential (expressed by GDP value, for example), some strategic transport nodes (e.g. airports or motorway junctions) or certain services (e.g. authority offices or hospitals) there are often considered (Chojnicki et al. 2011). 
Finally, to establish distance metrics and manner of potential expression one superior rule is assumed. Namely, taking into consideration a broad variety of opportunities and variants, authors tried to elaborate as general assessment of peripherality as possible. Therefore the distance between a pair of spatial units is defined as the length of the shortest line between the functional centres of the biggest settlements within each of these units. Such a definition, although relatively abstract, makes it possible to avoid the influence of many specificities of the different possibilities of accessibility or distance expressions more realistic. On the other hand, the major disadvantage of such a solution is the fact, that results achieved cannot be easily interpreted and directly implemented, e.g. in the planning of transport systems. Also in the case of potential, the most general solutions were chosen. The assessment of location was conducted in the context of demographic potential, because spatial distribution of the population strongly influences the spatial pattern of many other potentials.

In general, there are three basic approaches to location assessment: 1) distance-based measures, 2) isochrone-based or equidistant-based measures and 3) potential-based measures (Komornicki et al. 2010). The distance-based measures rely on measuring the distance to certain destinations, physical, temporal or economic. Distance to the most accessible destination (Ingram 1971) or sum of the distances to different destinations can be taken into consideration which is called topological accessibility (Garrison 1960). The basic advantages of this approach are relative ease of obtaining data and interpreting the results. Also a fluent change in these index values in space corresponds quite well to the fluent change of intensity in a location's peripheral features. The most important disadvantage of this approach is subjectivity of criteria defining centres, which are composed of a set of potential destinations. The impact of these criteria on the results of delimitation is illustrated in Figure 2. Also equalization of importance of these destinations should be treated as an imperfection of such an approach, because the weight of distance to the national capital city and to each of the other regional centres is the same. Moreover, by only taking into consideration the distance to the most accessible destination, the significance of distances to other potential destinations is also reduced. In this way, an area of good accessibility to two very important destinations can have a worse index value than an area of good accessibility to one, relatively less important destination.

The isochrone-based or equidistant-based measures rely on the estimation of potential of so called catchment areas (Śleszyński and Komornicki 2009). The limits of these areas are constituted by izochrones, lines of equal travel time, or equidistants, lines of equal distance from a given place (Spiekermann and Wegener 1996; Schurmann et al. 1997; Vickerman et al. 1999; Spiekermann and Neubauer 2002). Such analyses are conducted for the delimitation of market areas, e.g. the estimation of the number of potential customers or the labour market for a new employer, or the optimization of location of different objects, e.g. services, shopping centres etc. This approach also has both advantages and disadvantages which are quite similar to the previous approach. However, in this case values of the index are changing more sharply in the area than in the previous approach, especially between spatial units distant to an important potential slightly below and narrowly over a critical value (Fig. 3).

The potential-based measures are the most abstract, but the most objective simultaneously. The concept of a potential model to the social sciences was introduced by Ravenstein (1885), and to spatial economy by Isard (1954). In geography this concept 
was first applied to estimate market potential in the analysis of localization (Harris 1954). The first direct reference to a potential model to the sum of quotients of a destination's attractiveness (masses) and their travel times or costs (distance) was proposed by Hansen (1959). In the next decades, models of potential and models of gravity ${ }^{1}$ have become very popular in geography and have been applied and modified by many authors. The final value of index applied in this paper is expressed in number of population per sq. km, which is difficult to interpret. Hence the results are very often presented in percentage values. Nevertheless, advantages of this approach can be perceived as more valuable (Komornicki et al. 2010). First of all, this approach gives a relatively objective final result. The investigator is not obliged to assume any critical values. Whole spatial distribution of the potential in the area of investigation is included, regardless of the size of potential in a given spatial unit or its remoteness. The only assumption, which the investigator has to define is function, which should be applied to calculate adequate individual weight of each unit's potential. The fluent characteristic of the index values changes in the space is a comprised additional virtue of such an approach (Fig. 4).

\section{Empirical results of the delimitation of peripheries of Visegrad countries}

The whole area of investigation, although consisting of four different countries, is relatively comparable in the sense of population spatial distribution. The most important diversification is related to administrative units' size, especially between LAU 2 (Table 1). Population density, although significantly diverse at regional or local level, is relatively similar among the four countries analysed at national level (see Novotný et al. 2015). Also spatial distribution of urban centres is relatively regular. The three biggest cities in the area with more than 1 million inhabitants each are distributed in different countries. There are 7 cities exceeding 500 thousand inhabitants, 23 exceeding 200 thousand, 54 exceeding 100 thousand and 136 exceeding 50 thousand inhabitants within the Visegrad area. The network of urban centres in the area is quite regular.

Table 1. Comparison of LAU 1 and LAU 2 size

\begin{tabular}{|l|c|c|c|c|c|c|}
\hline \multirow{2}{*}{ Spatial extent } & \multicolumn{3}{|c|}{ LAU 1 } & \multicolumn{2}{c|}{ LAU 2 } \\
\cline { 2 - 7 } & Number & $\begin{array}{c}\text { Average } \\
\text { area } \\
\text { [sq. km] }\end{array}$ & $\begin{array}{c}\text { Average } \\
\text { population } \\
\text { number }\end{array}$ & Number & $\begin{array}{c}\text { Average } \\
\text { area } \\
\text { [sq. km] }\end{array}$ & $\begin{array}{c}\text { Average } \\
\text { population } \\
\text { number }\end{array}$ \\
\hline Czechia & 77 & $1,021.8$ & $136,524.9$ & 6253 & 12.6 & $1,684.5$ \\
Hungary & 174 & 533.1 & $56,766.5$ & 3154 & 29.4 & $3,131.7$ \\
Poland & 380 & 822.8 & $101,304.4$ & 2479 & 126.1 & $15,528.7$ \\
Slovakia & 72 & 679.0 & $74,977.8$ & 2890 & 16.9 & $1,868.2$ \\
Visegrad countries & 703 & 758.2 & $91,442.2$ & 14776 & 36.1 & $4,352.0$ \\
\hline
\end{tabular}

Source: own compilation.

1 The model of potential estimates the sum of influences of all potentials on a point located in a given area and the model of gravity estimates the sum of interactions between the given, having its own mass, and other potentials. 
To make the resulting values of different indices comparable, they were classified into four peripheral zones of different intensity of "peripherality", from A to D, and one non-peripheral zone. Zone A has been defined as the area of the most peripheral values of given index, where $5 \%$ of the population of the investigated area lives. Zone $B$ includes $10 \%$ of the population of the whole Visegrad area, zone C includes $20 \%$ and zone D 50\%.

The necessary condition to conduct delimitation of peripheries in each of the three indicated approaches is the homogenous character of spatial units. Unfortunately in the case of Visegrad countries, there are significant disparities in the lowest level units' size. Rural municipalities in Poland consist of a couple of villages, while in the other three countries one municipality is usually equal to one settlement. Therefore the average municipality in Poland is over four times larger than in Hungary, over seven times larger than in Slovakia and over ten times larger than in Czechia. Disparities between Visegrad countries in the population size of LAU 1 are lower and they do not exceed $100 \%$. That is why LAU 1 were applied to conduct the common analysis of Visegrad countries (Table 1).

The application of different approaches allowed the revealing and validating of some regularity in the peripheries spatial distribution. On the other hand a decided influence of assumptions on the final result has been proven (for some basic values see Table 2).

When applying distance-based measures a vast peripheral area appears in the south-west and south of Hungary when taking into consideration cities with 200,000 or more inhabitants (Fig. 2 left). This reflects the dominant position of Budapest in the Hungarian urban system and an absence of cities exceeding such population size in the western part of the country. It is necessary to note that this analysis dismisses cities outside Visegrad countries area, such as Berlin and Vienna, or smaller such as Graz or Zagreb that are located in the vicinity of the analysed territory. Attributing the role of centres to smaller and smaller cities, the distribution of central and peripheral areas changes. When taking into account also towns with at least 50,000 inhabitants, delimitated peripheral zones mostly have an internal character of regional importance and are rather dispersed. They can be named rather as interregional peripheries than peripheries of Visegrad countries (Fig. 2 right).

Also in the case of the equidistant-based measures, transition from general to detailed scale of analysis can be easily observed. When equidistance of $200 \mathrm{~km}$ is taken into consideration, the geometric position within Visegrad area plays the most important role. It is also because such a distance from a given LAU 1 often exceeds the external border of Visegrad countries. In such cases the number of units within equidistant is reduced, which strongly affects the total potential of the given place. Thus the most peripheral zones stretch along the outskirts of the analysed area (Fig. 3 left). When considering equidistance of $10 \mathrm{~km}$, the distribution of peripheral areas is much more fragmented (Fig. 3 right). Peripheral areas are adjusting to the shapes of less populated areas, which is evoked by an increase in the influence of less important urban centres. In this case, some similarities between the distribution of peripheral and rural areas are observed, when rural areas are delimited on the basis of population density.

In the third, the most complex approach employing the potential index, some kind of summary has been achieved. The method applied in the investigation concerning $\mathrm{Vi-}$ segrad countries relies on the summarizing potentials of all other spatial units divided by the function of space resistance (distance impact). In this investigation the quadratic function of distance has been applied, which emphasizes the impact of the characteristic 

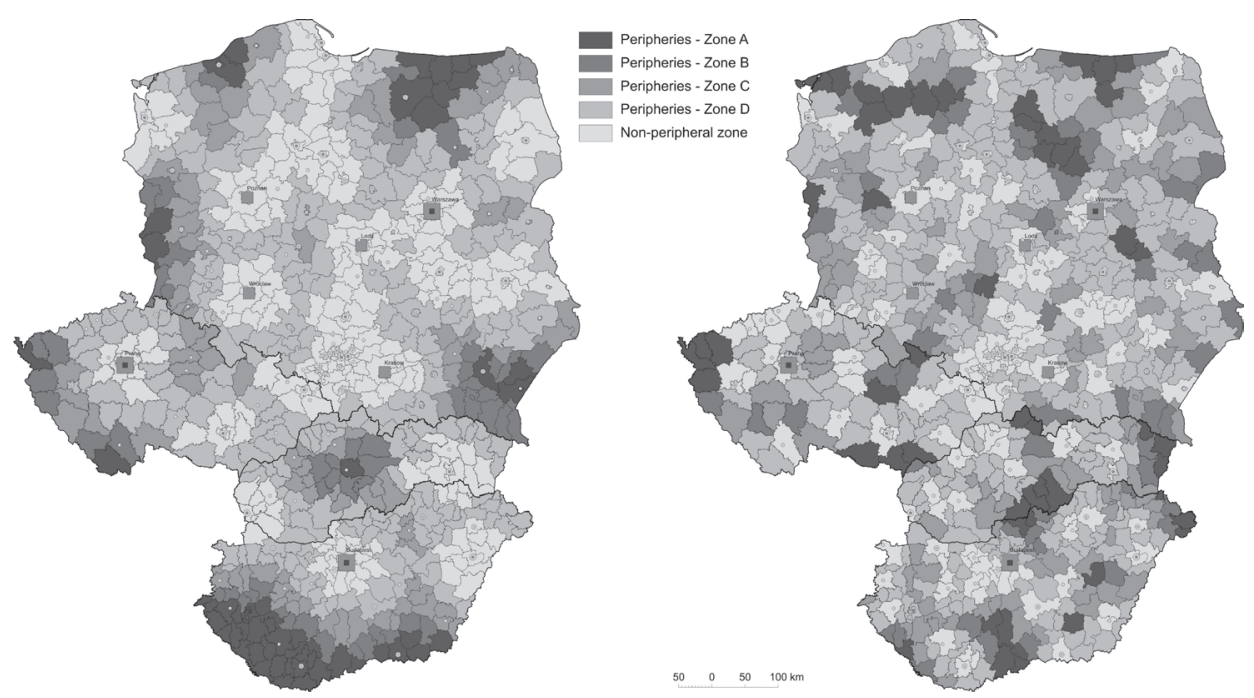

Fig. 2. Visegrad countries peripheries according to the distance to the closest city, depending on the city size: 200,000 or more inhabitants (left) and 50,000 or more inhabitants (right).

Source: designed by M. Mazur.

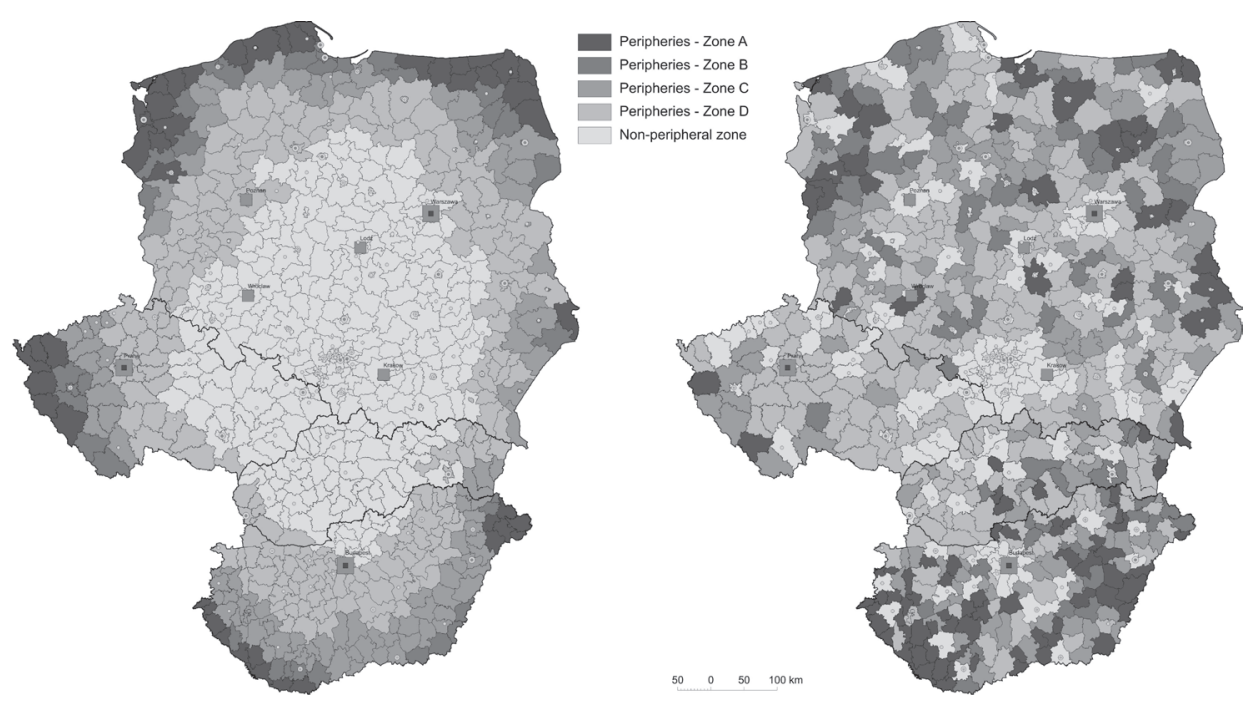

Fig. 3. Visegrad countries peripheries according to the number of population in the vicinities, depending on the equidistance: $200 \mathrm{~km}$ (left) and $10 \mathrm{~km}$ (right).

Source: designed by M. Mazur.

in the closest vicinity. The impact of further centres declines sharply. Thanks to this the advantage of location in suburbs plays a more important role than the central position in the context of spatial distribution of potential on the whole area. Two of the most important peripheries of the investigated area have been delimited as a consequence (Fig. 4). The northern periphery is located in the north-eastern fringes of Poland, spreading along the border from the Baltic Sea to Białystok. The second such area recognized is in the 


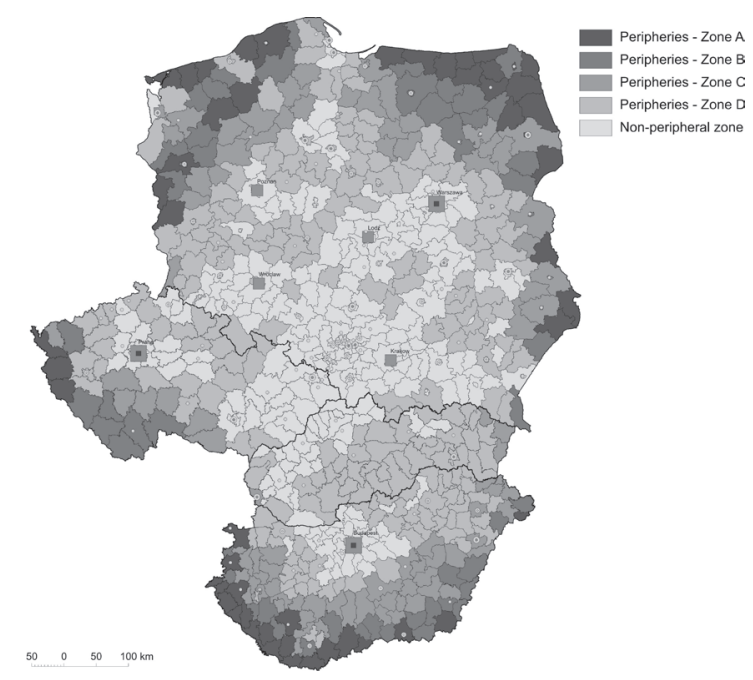

Fig. 4. Visegrad countries peripheries according to the value of potential index Source: designed by M. Mazur.

south-western fringes of Hungary, spreading along the Slovenian, Croatian and western part of the Serbian border. The smaller peripheral areas are located along the external borders of the investigated area as well, in less populated parts of them especially. The transition from the centre of the investigated area and the surroundings of the biggest agglomerations towards the peripheries has a fluent character. It seems to be some kind of compromise between different possible assumptions leading to a different level of generalization and a balance of proportion between the significance of the fringes of the investigated area and spatial distribution of centres within it.

Table 2. Basic characteristics of delimited zones of peripheries in Visegrad countries

\begin{tabular}{|c|c|c|c|c|c|}
\hline Approach & Assumption & Zone A criteria & Zone B criteria & Zone C criteria & Zone D criteria \\
\hline \multirow{5}{*}{ 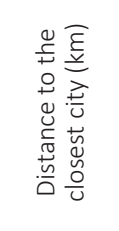 } & $\geq 1,000,000 \mathrm{inh}$ & 302.5 & 277.8 & 254.8 & 179.6 \\
\hline & $\geq 500,000 \mathrm{inh}$. & 218.5 & 195.5 & 167.1 & 99.1 \\
\hline & $\geq 200,000 \mathrm{inh}$. & 135.4 & 112.9 & 89.3 & 50.7 \\
\hline & $\geq 100,000$ inh. & 89.4 & 76.9 & 61.9 & 31.9 \\
\hline & $\geq 50,000$ inh. & 53.0 & 45.2 & 36.5 & 15.8 \\
\hline \multirow{5}{*}{ 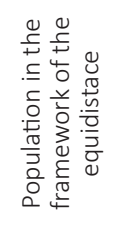 } & 200 km & $6,002,374$ & $6,952,592$ & $8,963,885$ & $13,395,495$ \\
\hline & 100 km & $1,290,133$ & $1,709,118$ & $2,498,619$ & $3,999,983$ \\
\hline & $50 \mathrm{~km}$ & 381,756 & 484,923 & 612,434 & 996,830 \\
\hline & $20 \mathrm{~km}$ & 58,401 & 72,701 & 96,922 & 181,762 \\
\hline & 10 km & 19,916 & 25,331 & 33,927 & 70,268 \\
\hline 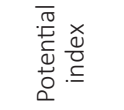 & $P_{i}=\sum_{j=1}^{n-1} \frac{P_{j}}{t_{i j}^{2}}$ & $1085.2 / \mathrm{km}^{2}$ & $1337.0 / \mathrm{km}^{2}$ & $1755.1 / \mathrm{km}^{2}$ & $2616.5 / \mathrm{km}^{2}$ \\
\hline
\end{tabular}




\section{Conclusion}

Peripheries are generally understood strictly, as an attribute of location in relation to spatial distribution of potential. With such an approach it seems to be necessary to use peripheries as one of the hypothetical barriers of rural enterprise development, a way of explaining the specific circumstances of their activities, instead of defining an unfavourable situation by the problem area itself, idem per idem. Following the broader approach to the concept of peripheries, overcoming peripheral location by enterprises would mean becoming non-peripheral. At the same time empirical analysis indicated some examples of peripheral areas, which have relatively favourable conditions for entrepreneurship development, e.g. coastal areas or transit areas between major urban centres of Visegrad countries and Berlin, Vienna or the Baltic countries. A more advanced analysis of peripherality should additionally include at least two aspects: external development cores and road network layout and quality. However, for the purposes of this elaboration, an approximation based on the shortest physical distance seems to be enough to indicate an area of special interest for entrepreneurship development support. The presented analysis has also proven that despite some possible similarities between spatial distribution of rural and peripheral areas, which rise from population density and distribution of urban cores into identification of both kinds of areas, it is not possible to describe them as regularities. Especially at the more general level the analyses identified peripheral areas also including relatively big urban centres while many rural areas were included into the non-peripheral regions. Hereby the importance of spatial scale in the research of peripheries has been confirmed.

The results presented in this article are partially outcome of the project VEGA 1/0473/14: Dynamic 3-D modelling of urban landscape with a multiscale approach. The preparation of this article was also supported by a grant from the Hungarian Scientific Research Fund (OTKA) Grant Agreement no. K 105534.

\section{References}

Andreoli M., 1994, Development and marginalization in Liguria Region, [in:] Chang-Yi D. Ch. et al. (eds), Marginality and development issues in marginal regions. Proceedidngs of IGU Study Group, National Taiwan University and IGU, Taipei, pp. 41-61.

Blažek J., Uhlír D., 2002, Teorie regionálního rozvoje. Nástin, kritika, klasifikace, Karolinum, Praha.

Borgatti S., Everett M., 2000, Models of Core/Periphery structures, Social Networks, 21, pp. 375-395.

Castree N., Kitchin R., Rogers A., 2013, Dictionary of Human Geography, Oxford University Press, Oxford.

Čermák L., 2005, Hodnocení vztahu dopravni dostupnosti a exponovanosti území, [in:] Novotná M. (ed), Problémy periférních oblastí, Univerzita Karlova v Praze, Přírodovědecká fakulta, KSGaRG, Praha, pp. 44-52.

Chojnicki Z., Czyż T., Ratajczak W., 2011, Model potencjału. Podstawy teoretyczne i zastosowania w badaniach przestrzenno-ekonomicznych oraz regionalnych, Bogucki Wydawnictwo Naukowe, Poznań. 
Garrison W. L., 1960, Connectivity of the Interstate Highway System, Papers of the Regional Science Association, 6, pp. 121-137.

Gurung G. S., Kollmair M., 2005, Marginality: Concepts and their Limitations, Development Study Group, Department of Geography, University of Zurich, Zurich.

Halás M., 2014, Modelovanie priestorového usporiadania a dichotómie centrum - periféria, Geografie, 119, pp. 384-405.

Halás M., 2008, Priestorová polarizácia spoločnosti s detailným pohladom na periférne regióny Slovenska, Sociologický časopis (Czech Sociological Review), 44, pp. 349-369.

Hansen W., 1959, How Accessibility Shapes Land-use, Journal of the American Institute of Planners, 25, pp. 73-76.

Harris C., 1954, The Market as a Factor in the Localization of Industry in the United States, Annals of the Association of American Geographers, 44, pp. 315-348.

Havlíček T., 2003, Are border regions peripheral territories? [in:] Kowalczyk A. (ed), Theoretical and Methodological Aspects of Geographical Space at the Turn of Century, Warsaw University, Faculty of Geography and Regional Studies, Warsaw, pp. 193-198.

Havlíček T., Chromý P., 2001, Př́spěvek k teorii polarizovaného vývoje územi se zaměřením na periférni oblasti, Geografie, 106, pp. 1-11.

Havlíček T., et al., 2005, Vybrané teoreticko-metodologické aspekty a trendy geografického výzkumu perifernich oblasti, [in:] Novotná, M. (ed), Problémy periférnich oblasti, Univerzita Karlova v Praze, Př́rodovědecká fakulta, KSGaRR, pp. 6-24.

Horňák M., 2006, Identification of Regions of Transport Marginality in Slovakia, [in:] Komornicki T., Czapiewski K. (eds), Europa XXI - Regional Periphery in Central and Eastern Europe, Institute of Geography and Spatial Organization, Warsaw, pp. 35-41.

Hurbánek P., 2004, Zmena úlohy priestorového aspektu v interpretáciách pojmov periférnost' (marginalita) a vidiek, [in:] Wahla, A. et al. (eds), Geografie a proměny poznání prostorové reality - Sborník príspěvků, Ostravská Univerzita, Ostrava, pp. 102-110.

Ingram D., 1971, The Concept of Accessibility: a Search for an Operational Form, Regional Studies, 5, pp. 101-107.

Isard W., 1954, Location Theory and Trade Theory: Short-Run Analysis, Quarterly Journal of Economics, 68, pp. 305-322.

Jussila H., 1998, Marginality in regional policy research: a view from the Nordic countries, [in:] Jussila H., Leimgruber W., Majoral R. (eds), Perception of Marginality: theoretical issues and regional perceptions of marginality, Ashgate Publishing, Aldershot, pp. 217-235.

Kohli A., 2004, State-directed development. Political Power and Industrialization in the Global Periphery, Cambridge University Press, Cambridge.

Komornicki T., Śleszyński P., Rosik P., Pomianowski W., 2010, Dostępność przestrzenna jako przesłanka kształtowania polskiej polityki transportowej, Biuletyn KPZK PAN, 241, Warsaw.

Leimgruber W., 1994, Marginality and marginal regions: problems of definition, [in:] Chang-Yi D. Ch. et al. (eds), Marginality and development issues in marginal regions. Proceedidngs of IGU Study Group, National Taiwan University and IGU, Taipei, pp. 1-18.

Máliková L., Spišiak P., 2013, Vybrané problémy marginality a periférnosti vidieckych regiónov na Slovensku, Acta Geographica Universitatis Comenianae, 57, pp. 51-70.

Novotný L., Hruška V., Egedy T., Mazur M., 2015, Defining rural areas of Visegrad countries, Studia Obszarów Wiejskich, 39, pp. 21-34.

Pelc S., 2007, Geographical marginality as a research topic in Slovenian geography, Geografski vestnik, 84, pp. 209-217. 
Poláčková L., Potomová J., 2010, Problematika vymedzovania marginálnych regiónov v plánovacích dokumentoch SR, Geographia Cassoviensis, 4 (1), pp. 135-139.

Ravenstein E., 1885, The Laws of Migration, Journal of the Statistical Society, 46, pp. 167-235.

Reynaud A., 1981, Société, espace et justice: inéhalités régionales et justice socio-spatiale, Presses universitaires de France, Paris.

Schmidt M., 1998, An integrated systemic approach to marginal regions: from definition to development policies [in:] Jussila H., Leimgruber W., Majoral R. (eds), Perception of Marginality: theoretical issues and regional perceptions of marginality, Ashgate Publishing, Aldershot, pp. 45-66.

Seidl T., Chromý P., 2010, Problémy integrace marginálního území do regionálního systému: Př́klad vojenského újezdu Boletice, Geografie, 115, pp. 44-63.

Schurmann C., Spiekermann K., Wegener M., 1997, Accessibility Indicators: Model and Report, SASI Deliverable D5. Report to the European Commission, Berichte aus dem Institut fur Raumplanung 39, Institute of Spatial Planning, Dortmund.

Śleszyński P., Komornicki T., 2009, Wpływ rozwoju sieci drogowej na obszary rynkowe istniejqcych i planowanych portów lotniczych (2008-2015), Drogi. Lądowe, powietrzne, wodne, 9, pp. 91-99.

Spiekermann K., Neubauer J., 2002, European Accessibility and Peripherality: Concepts, Models and Indicators, Nordregio Working Paper, Stockholm.

Spiekermann K., Wegener M., 1996, Trans-European Networks and Unequal Accessibility in Europe, European Journal of Regional Development, 4, pp. 35-42.

Spišiak P., 2000, Pol'nohospodárstvo v marginálnych oblastiach Slovenska, Životné prostredie, 34, pp. 15-19.

Šebová L., 2013, Identifikácia marginálnych regiónov na Slovensku, PhD thesis, Bratislava, Comenius University.

Vickerman R., Spiekermann K., Wegener M., 1999, Accessibility and Economic Development in Europe, Regional Studies, 33, pp. 1-15. 